\title{
PERBEDAAN PERILAKU PROSOSIAL DAN SELF AWARENESS TERHADAP NILAI BUDAYA LOKAL JAWA DI TINJAU DARI JENIS KELAMIN PADA SISWA SMA KYAI AGENG BASYARIYAH KECAMATAN DAGANGAN KABUPATEN MADIUN
}

\author{
Elza Kusumaningrum* \\ elzakusma93@yahoo.com \\ Noviyanti Kartika Dewi** \\ noviyantibk411@gmail.com
}

\begin{abstract}
Abstrak
Pada dasarnya siswa yang memiliki perilaku prososial yang baik akan mudah diterima di lingkungan masayarakat, memiliki perilaku prososial adalah cara meminimalisir tumbuh suburnya sikap individualis di kalangan siswa baik pada siswa laki-laki maupun perempuan. Selain itu, kesadaran diri siswa terhadap nilai budaya jawa juga perlu dipertahankan, karena remajalah yang akan mewarisi nilai lokal budaya jawa ini. Kesadaran diri penting karena memiliki kesadaran diri membuat remaja mengetahui akan kelebihan dan kekurangan masing-masing, seseorang akan mampu memahami konsep diri dan standar, nilai serta tujuan yang dimiliki seseorang.

Penelitian ini bertujuan untuk mengetahui ada tidaknya perbedaan perilaku prososial dan self awareness (kesadaran diri) terhadap nilai-nilai lokal budaya jawa di tinjau dari jenis kelamin pada siswa SMA Kyai Ageng Basyariyah Kecamatan Dagangan Kabupaten Madiun tahun pelajaran 2015/2016. Rancangan penelitian menggunakan pendekatan metode deskriptif kuantitatif. Penentuan sampel dalam penelitian ini menggunakan teknik random sampling yaitu mengambil 60 siswa. Yang terdiri dari 30 siswa perempuan dan 30 siswa laki-laki. Pengumpulan data menggunakan metode skala sikap. Dalam menganalisis data menggunakan teknik analisis uji-t.

Hasil penelitian menunjukan bahwa : (1) Ada perbedaan perilaku prososial siswa perempuan dan laki-laki kelas X SMA Kyai Ageng Basyariyah Kecamatan Dagangan Kabupaten MadiunTahun Pelajaran 2015/2016, hal tersebut dengan ditunjukkan $r_{\text {hitung }}=4,222>t_{\text {tabel }}=1,671$ (2) Ada perbedaan perilaku prososial dan self awareness terhadap nilai-nilai lokal budaya jawa anatara siswa perempuan dan laki-laki SMA Kyai Ageng Basyariyah Kecamatan Dagangan Kabupaten MadiunTahun Pelajaran 2015/2016, hal tersebut dengan ditunjukkan $\mathrm{r}_{\text {hitung }}=$ $4,327>t_{\text {tabel }}=1,671$. Ini berarti ha diterima dan ho ditolak.
\end{abstract}

Kata Kunci : Perilaku Prososial, Self Awarenes (Kesadaran Diri),Nilai-Nilai Lokal Budaya Jawa, di Tinjau dari Jenis Kelamin.

* Elza adalah Mahasiswa Program Studi Bimbingan dan Konseling Fakultas Ilmu Pendidikan IKIP PGRI MADIUN

** Noviyanti Kartika Dewi adalah Dosen Program Studi Bimbingan dan Konseling Fakultas Ilmu Pendidikan IKIP PGRI MADIUN 


\section{PENDAHULUAN}

Setiap budaya pasti memiliki kekhasannya sendiri yang sering kali menjadi ikon kebanggaan masyarakat pendukungnya. Jawa merupakan salah satu suku yang memiliki beragam kebudayaan yang khas. Nilai-nilai lokal jawa ini dapat digali dan dimanfaatkan untuk mencapai kesuksesan. Nilai karakter lokal merupakan penanaman sikap dan kepribadian kepada siswa untuk investasi kehidupan kelak dalam masyarakat. Pendidikan karakter tidak dapat diajarkan melalui prosesproses kognitif, melainkan melalui pengembangan pembiasaan dan penanaman nilai secara inklusif yang terintegrasi dengan semua piranti pendidikan dan pembelajaran di sekolah.

Dalam praktek sehari-hari, masyarakat jawa menjalankan tata karma jawa yang terdiri dari empat keutamaan yaitu, bersikap sesuai dengan derajat masing-masing pihak dan saling menghormati kedudukan masing-masing. Menyatakan sesuatu secara tidak langsung melalui "senepo" atau kiasan, bersikap menghormati hal-hal yang bersifat pribadi dengan seakan-akan tidak mengetahui masalah pribadi orang lain, dan mengindari ucapan atau sikap yang menunjukkan ketidakampuan mengontrol diri.

Empat hal tersebut adalah nilai ideal yang seharusnya ada pada masyarakat jawa. Namun dalam kenyataannya saat ini dapat di temui peristiwa-peristiwa yang ada pada masyarakat jawa khususnya pada remaja jawa yang tidak sesuai dengan nilai-nilai budaya jawa. Remaja jawa sebagai pewaris budaya jawa saat ini dalam banyak penelitian mengenai nilai budaya jawa dengan berbagai dinamikanya banyak mengalami penurunan sikap dan perilaku terhadap nilai budaya jawanya (Rachim dan Nashori,2007: 31)

Salah satu permasalahan yang muncul antara lain terkait dengan permasalahan kesadaran diri individu terhadap nilai-nilai budaya jawa. Nilai jawa yang telah memudar dalam kehidupan siswa antara lain nilai sosial, seperti pada ungkapan jawa yaitu "mikul dhuwur mendem jero" yang bisa diartikan dengan kesadaran bahwa kita harus menutupi kesalahan teman kita, dan menjunjung segala yang baik tentang nya dan harus berbicara yang baikbaik saja tentang dirinya kepada orang lain. Realitanya banyak di lakangan siswa yang bercerai berai, dan rata-rata permasalahan yang timbul yaitu karena siswa terkadang membicaran keburukannya pada orang lain. Hal tersebut menimbulkan permasalahan pada siswa.

Selain itu sikap dan perilaku prososial, dimana sikap saling 
menolong dan membantu orang lain dikalangan siswa juga telah memudar. Hal ini terjadi akibat tumbuh suburnya sikap individualis dilakangan siswa. Banyak siswa yang cuek dan enggan membantu temannya. Mereka akan sibuk dengan keperntingannya masingmasing, apalagi dengan kemajuan teknologi mereka akan sibuk dan lebih focus pada gadged masingmasing dan mengabaikan lingkungan sekitarnya, akibatnya semakin banyak siswa yang melakukan perilaku antisosial.

Dalam penelitian yang dilakukan oleh Zimmer-Gembeck, dkk. (2005) ditemukan bahwa kecenderungan untuk menolong pada anak-anak remaja lebih besar pada remaja perempuan dibandingkan dengan remaja laki-laki. Namun, studi pada anak-anak berbakat intelektual dan anak-anak tidak berbakat intelektual di dua sekolah menengah atas di Jakarta menunjukkan bahwa tidak terdapat perbedaan jenis kelamin dalam kecenderungan menolong anak-anak berbakat intelektual. Namun, terdapat perbedaan jenis kelamin pada anak-anak tidak berbakat intelektual, anak perempuan lebih positif dibandingkan anak lakilaki dalam menolong Hartati (dalam Sarwono dan Meinarno, 2014: 136). Perbedaan stereotype pria dan wanita menyebabkan perbedaan dalam perilaku prososial antara pria dan wanita. Berndt (dalam Asih \& Pratiwi, 2010: 38) menyatakan bahwa anak perempuan lebih mudah merasa tidak enak jika melihat orang lain mengalami kesusahan. Sehubungan dengan fenomena diatas maka peneliti tertarik untuk melakukan penelitian tentang perbedaan perilaku prososial dan self awareness terhadap nilai-nilai budaya lokal jawa di tinjau dari jenis kelamin.

\section{Perilaku Prososial.}

Dalam

khasanah psikologi, istilah tingkah laku prososial bukanlah hal yang baru. Sejumlah ahli telah berusaha mempelajari tingkah laku tersebut dan mencoba untuk merumuskan definisi yang dianggap dapat memberikan penjelasan. Sears dkk (dalam Desmita, 2014: 235), misalnya, secara sederhana mendefinisikan tingkah laku prososial sebagai tingkah laku yang menguntungkan orang lain. Sehingga tingkah laku prososial menurut Sears mencangkup kategori yang lebih luas; meliputi segala bentuk tindakan yang dilakukan atau merencanakan untuk menolong orang lain, tanpa memperdulikan motifmotif si penolong. Lebih lanjut Widyastutui (2014: 107) menjelaskan perilaku prososial berkisar dari tindakan altruism yang tanpa 
pamrih atau tidak mementingkan diri sendiri sampai tindakan menolong yang sepenuhnya dimotivasi oleh diri sendiri.

Tingkah laku prososial menyangkut intense, value, empati, proses-proses internal dan karakteristik individual yang dapat mengantarai suatu tindakan. Fokus utamanya adalah tindakan, kerena hal ini signifikan untuk individu dan kelompok sosial. Seseorang di tolong dengan tindakan, tidak dengan belief. Values, empati dan proses internal lainnya adalah penting sebagai motivator tingkah laku prososial. Evaluasi diri terhadap perasaan puas dan kebahagiaan dipengaruhi oleh ketaatan terhadap internalisasi nilai-nilai moral yang dianut, akhirnya akan mengantarkan seseorang kepada tingkah laku prososial.

\section{a. Sumber Tingkah Laku Prososial}

Mengenai sumbersumber tingkah laku prososial, Derlega \& Grzalek (dalam Desmita, 2014: 238239) membagi dua bagian yaitu:

Endosentris. Salah satu sumber tingkah laku prososial adalah berasal dari dalam diri seseorang yang disebut sebagai sumber endosentris. Sumber endosentri adalah keinginan untuk mengubah diri, yaitu menujukkan selfimage positif yang berfokus kepada aspek self-moral. Secara keseluruhan endosentris ini menguatkan konsep diri (self concept). Salah satu bentuk selfconcept adalah selfexpectations bahagia, kebanggaan, rasa aman, evaluasi diri yang positif.

Eksosentris. Sumber eksosentris adalah sumber untuk memerhatikan dunia eksternal, yaitu memajukan, membuat kondisi lebih baik dan menolong orang lain dari kondisi buruk yang dialami.konsep dasar memajukan orang lain adalah karena adanya :

1) Kesadaran bahwa orang membutuhkan bantuan (pencapaian tujuan bervalensi positif).

2) Aktor dan orang yang membutuhkan bantuan dihubungkan oleh hubungan sosial yang "memajukan", misalnya aktor harus berfikir sebagai "kita" terhadap orang yang membutuhkan 


$$
\begin{aligned}
& \text { pertolongan, bukan } \\
& \text { berfikir } \\
& \text { "mereka". }
\end{aligned}
$$

Pada prinsipnya tingkah laku prososial terjadi karena "ada yang memberi dan ada yang menerima" pertolongan.

Dalam situasi tersebut terdapat saling ketergantungan antara yang menolong dengan yang ditolong. Pemberian pertolongan memerlukan situasi khusus, yaitu situasi ketergantungan, dimana seseorang yang membutuhkan pertolongan tergantung pada orang lain yang memberikan pertolongan.

\section{b. Aspek-Aspek Perilaku Prososial.}

Terdapat beberapa macam perilaku prososial. Menurut Mussen dkk (dalam Ifada Meihati, Sukarti \& Moh. Nu'man, 2009: 11-12) aspek-aspek perilaku prososial yaitu :

Membagi
Membagi memiliki
pengertian bahwa
individu yang memiliki
kecukupan untuk saling
membagi kelebihannya
tersebut baik materi
maupun rilmu
pengetahuannya kepada
orang lain.

2) Bekerja sama

Bekerjasama

merupakan suatu

bentuk perilaku yang sengaja dilakukan oleh sekelompok orang maupun organisasi demi terwujudnya suatu cita-cita yang diinginkan bersama.

3) Menolong

Menolong merupakan suatu tindakan sukarela tanpa memperdulikan untung maupun rugi dari tindakan menolong dan tanpa mengharapkan imbalan apa-apa dari orang yang ditolong.

4) Kejujuran

Kejujuran adalah suatu bentuk perilaku yang ditunjukkan dengan perkataan yang sesuai dengan keadaan dan tidak menambahkan atau mengurangi kenyataan yang ada.

5) Dermawan

Tindakan dermawan adalah suatu perilaku yang menjukkan rasa kemanusiaan dengan cara memberikan sebagian hartanya kepada orang lain yang membutuhkan. 
6) Mempertimbangkan hak dan kewajiban orang lain

Hak dan kewajiban merupakan hak asasi setiap manusia. Seorang individu yang memiliki sikap yang demikian ditujukkan dengan cara menghargai hak-hak orang lain sebelum meminta kewajibannya terlebih dahulu.

\section{c. Perilaku Prososial dan Gender.}

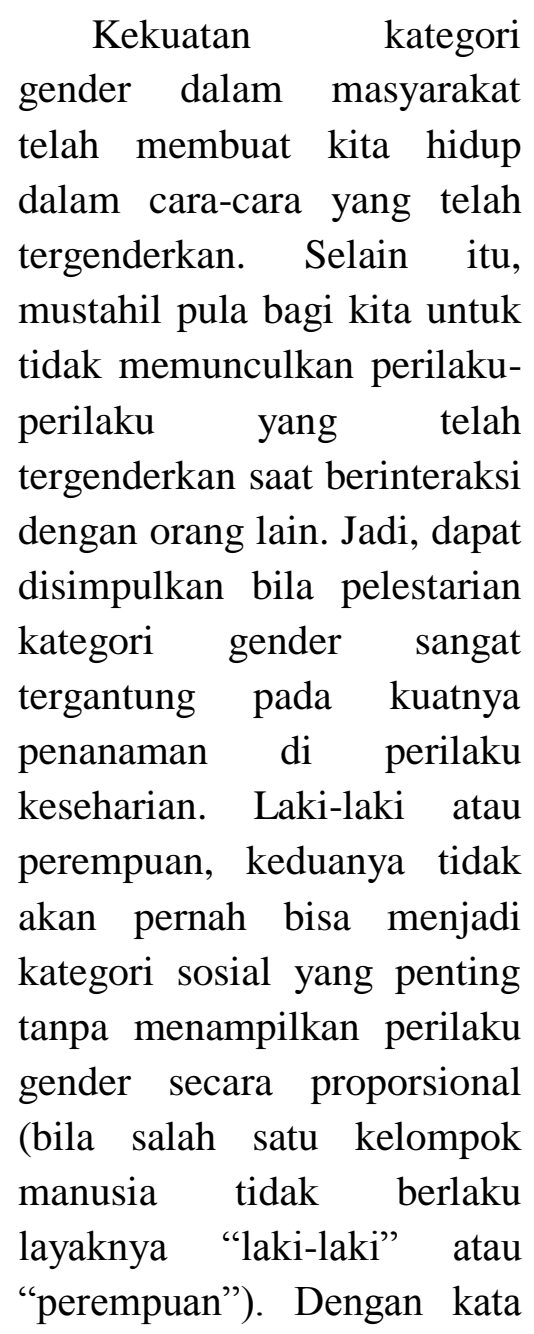

lain, orde gender dan kategori sosial (laki-laki maupun perempuan) mengada dalam praktik sosial (Sugihastuti \& Septiawan, 2007: 75-76)

Perbedaan pria dan wanita adalah prinsip universal dalam kehidupan sosial. saat masih anak-anak, pria dan wanita diharapkan menguasai ketrampilan yang berbeda dan mengembangkan kepribadian yang berbeda pula. Saat dewasa, pria dan wanita biasanya mengasumsikan peran gender seperti suami istri, ayah dan ibu. Kultur berbeda-beda dalam mendefinisikan maskulin dan feminism dan juga berbeda dalam hal sejauh mana perbedaan dan persamaan gender. Tetapi, penggunaan gender untuk menata kehidupan sosial merupakan aspek yang mendasar. Helgeson (dalam Taylor, 2009: 412).

Peran gender terhadap kecenderungan seseorang untuk menolong sangat bergantung pada situasi bentuk pertolongan yang dibutuhkan. Laki-laki cenerung lebih mau terlibat dalam aktivitas menolong pada situasi darurat yang membahayakan, misalnya menolong seseorang dalam kebakaran. Hal ini tampaknya 


\begin{abstract}
terkait dengan peran tradisional laki-laki, yaitu laki-laki dipandang lebih kuat dan lebih mempunyai ketrampilan untuk melindungi diri. Sementara perempuan, lebih tampil menolong pada istuasi yang bersifat memberi dukungan emosi, merawat dan mengasuh (deaux dkk(dalam Sarwono dan Meinarno, 2014: 136). Perbedaan stereotype pria dan wanita menyebabkan perbedaan dalam perilaku prososial antara pria dan wanita. Berndt (dalam Asih \& Pratiwi, 2010: 38) menyatakan bahwa anak perempuan lebih mudah merasa tidak enak jika melihat orang lain mengalami kesusahan.
\end{abstract}

\section{Self Awareness (Kesadaran Diri)}

a. Pengertian Self Awareness (Kesadaran Diri)

$\begin{array}{lr}\text { Self } & \text { awareness } \\ \text { (kesadaran diri) } & \text { adalah } \\ \text { perhatian yang berlangsung } & \text { ketika seseorang mencoba } \\ \text { memahami keadaan internal } & \text { dimana } \\ \text { dirinya. Prosesnya berupa } & \text { semacam refleksi dimana } \\ \text { seseorang secara sadar } \\ \text { memikirkan hal-hal yang ia } \\ \text { alami berikutnya emosi- } \\ \text { emosi mengenai pengalaman } \\ \text { tersebut. Dengan kata lain, }\end{array}$

self awareness adalah keadaan ketika kita membuat diri sendiri sadar tentang emosi yang sedang kita alami dan juga pikiran-pikiran kita mengenai emosi tersebut (Prasetyo, 2014).

\section{b. Karaktristik Self Awareness (Kesadaran Diri)}

Dalam penerapannya dikehidupan sehari-hari, self awareness atau lebih dikenal kesadaran diri memiliki beberapa ciri-ciri seperti yang diungkapkan Solso (dalam Ahmad, 2013) bahwa karakteristik kesadaran diri meliputi Attention, Wakefullnes, Architecture, Recacal of Knowledge dan Emotive.

1) Attention atau perhatian, ialah dimana pemusatan sumber daya mental ke hal-hal eksternal maupun internal. Individu memperhatikan suatu obyek dari luar dirinya untuk mendapatkan kesadaran tanggung jawab, selain isyaratisyarat eksternal, individu dapat mengalihkan perhatianperhatian ke dalam diri dan merenungkanpikiranpikiran pribadi, momorimemori, cita-cita, 
sehingga kesadaran diri akan dapat terbentuk.

2) Wakefull atau kesiagaan merupaka suatu kondisi mental yang dialami seseorang sepanjang hidupnya, dalam setiap hari.

3) Architecture sebuah aspek struktur fisikologis, dimana kesadaran bukanlah sebuah proses tunggal yang dilakukan oleh sebuah neuron tunggal, melainkan dipertahankan melalui sejumlah prosesproses neurologis yang diasosiasikan dengan interpretasi terhadap fenomena sensorik, motorik, kognitif, dan emosional, yang ada secara fisik maupun secara imajinatif.

Tindakan-tindakan tersebut tampaknya berlangsung otomatis sebagai hasil dari pengalaman. Tindakantindakan lain memerlukan intervensi sadar dan kompleks.

4) Reccal of knowledge adalah proses pengambilan informasi tentang pribadi yang bersangkutan dan dunia disekelilingnya.
Kesadaran memampukan manusia mendapatkan akses ke pengetahuan melalui proses recall dan rekognisi terhadap informasi mengenai diri pribadi dan mengenai dunia ini.

5) Emotive ialah suatu kondisi sadar, sebagai bentuk perasaan atau emosi. Emosi di timbulkan oleh kondisi internal saat individu merespon peristiwaperistiwa eksternal, saat individu berusaha mendeskripsikan emosiemosi subyektif tersebut kepada orang lain, perasaan-perasaan tersebut persis sebagai mana yang individu rasakan.

Terdapat perbedaan dalam seseorang memperhatikan aspek privat atau publik yang ada pada diri mereka. Perbedaan ini dinamakan "kesadaran diri publik" versus “ kesadaran diri privat" (Fenigstein, Scheier \& Buss dalam Taylor, Peplan \& Osears, 2009: 138). Kesadaran diri privat merupakan kondisi dimana perhatian difokuskan pada pikiran dan perasaan sendiri, sedangkan kesadaran diri 
publik merupakan kondisi dimana perhatian dipusatkan pada kesan dan orang lain. (Romlah, 2000: 30).

Orang dengan kesadaran privat yang tinggi tampaknya punya skema diri yang lebih baik, dan mereka lebih mengetahui disposisi internalnya. Ketika diri publik menjadi amat menonjol, orang cenderung akan memperhatikan sikap personalnya, tetapi ketika perhatian dialihkan ke luar, mereka mungkin akan lebih memperhatikan norma sosial. Bentuk kesadaran diri publik dan privat tidak bertentangan. Orang dapat berada dalam keduanya secara bersamaan. (dalam Kartika Dewi: 2013)

\section{c. Self Awareness (Kesadaran Diri) dan Gender}

Kita sering beranggapan bahwa laki-laki mempunyai sifat tertentu yang berbeda dari perempuan. Laki-laki dianggap tidak emosional, dependen dan sebagainya, sedangkan perempuan dianggap lemah, penuh kasih sayang, emosional, dependen dan sebagainya. Penelitian yang dilakukan oleh Williams dan kawan-kawan menujukkan, konsistensi perbedaan peran gender antara laki-laku dan perempuan, yaitu laki-laki selalu di pandang sebagai makluk yang aktif, kuat dan penyelesai masalah, sedangkan perempuan adalah makhluk yang lemah, pasif, dan perlu dilindungi. Namun sebenarnya stereotip tersebut tidak selamanya sama dengan gambaran hidup dalam masyarakat. Masih banyak perempuan-perempuan kuat dalam masyarakat yang bahkan menyaingi laki-laki (Sarwono, 2015: 110).

Disetiap negara, anak perempuan menghabiskan lebih banyak waktu membantu pekerjaan rumah tangga dan menjaga anak dan laki-laki menghabiskan lebih banyak waktu dengan bermain yang tidak diawasi (Edwards (dalam Myers, 2012: 239). Dari uraian diatas terlihat perbedaan diri antara perempuan dan laki-laki dari segi kepribadian maupun budayanya.

\section{METODE PENELITIAN.}

Metode yang akan digunakan dalam penelitian ini adalah metode penelitian Deskriptif Kuantitatif. Metode deskriptif kuantitatif yaitu suatu bentuk penelitian yang berdasarkan data yang dikumpulkan selama penelitian secara sistematis mengenai fakta-fakta dan sifat-sifat dari obyek yang diteliti dengan 
menggabungkan dua variabel yang terlibat didalamnya, kemudian diinterpretasikan berdasarkan teoriteori dan literature-literatur yang berhubungan dengan perbedaan perilaku prososial dan self awareness (kesadaran diri) terhadap nilai-nilai budaya jawa ditinjau dari jenis kelamin. Dalam penelitian ini peneliti memperoleh data dengan menggunakan skala psikologis, dimana data tersebut nantinya akan dihitung secara statistik.

Populasi dalam penelitian ini adalah siswa kelas X di SMA Kyai Ageng Basyariyah Dagangan Kabupaten Madiun. Populasi tersebar dalam beberapa kelas dengan kesamaan yang dijadikan dasar dalam pengambilan populasi. Sedangkan untuk menentukan sampel penelitian menggunakan teknik Proportional Random Sampling. Teknik pengumpulan data dalam penelitian ini menggunakan skala pengukuran yang dalam penelitian ini terdiri atas skala perilaku prososial dan skala self awareness (kesadaran diri). Secara keseluruhan penyusunan skala ini mengacu pada Skala Likert. Menurut Sugiyono (2013: 168) Skala Likert digunakan untuk mengukur sikap, pendapat, dan persepsi seseorang atau sekelompok orang tentang fenomena sosial. fenomena sosial dalam penelitian ini telah ditetapkan secara spesifik oleh peneliti, yang selanjutnya disebut sebagai variabel penelitian.

\section{HASIL DAN PEMBAHASAN}

Hasil penelitian tentang perbedaan perilaku prososial dan self awareness terhadap nilai-nilai lokal budaya jawa kepada 30 siswa perempuan dan 30 siswa laki-laki hasil adalah sebagai berikut

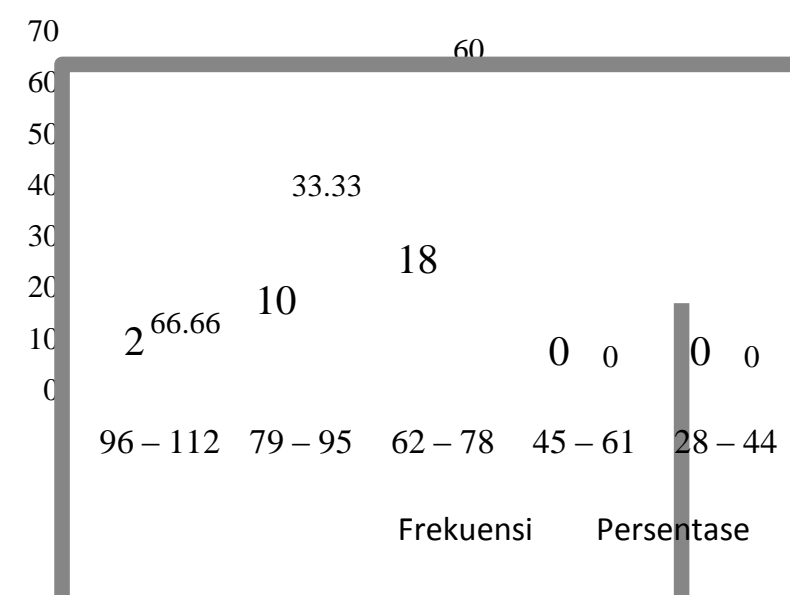

Gambar 4.1 Histogram distribusi Frekuensi Data Perilaku Prososial Siswa Perempuan 


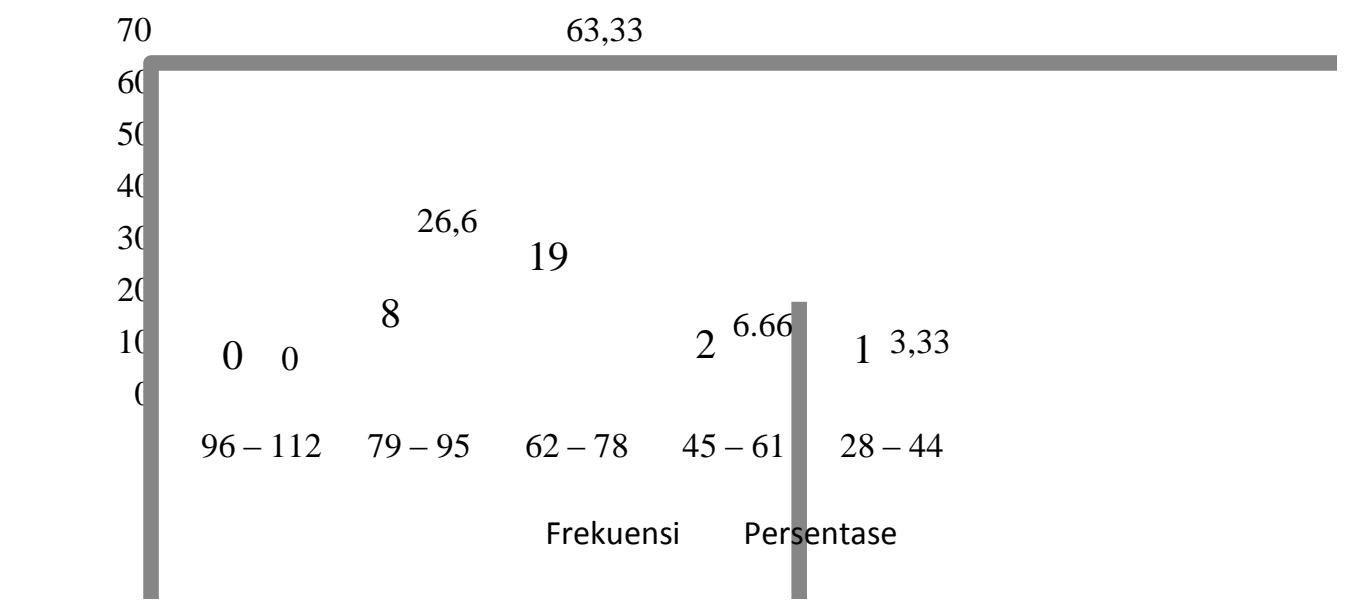

Gambar 4.2 Histogram distribusi Frekuensi Data Perilaku Prososial Siswa

Laki-Laki

2. Deskripsi data Self Awareness (Kesadaran Diri) Terhadap Nilai-Nilai Budaya Lokal Jawa.

Data yang diperoleh dari sampel sebanyak 60 siswa yang terdiri dari 30 siswa perempuan dan 30 siswa laki-laki hasil adalah sebagai berikut :



Gambar 4.3 Histogram Distribusi Frekuensi Data Self Awareness (Kesadaran Diri) Terhadap Nilai-Nilai Budaya Lokal Jawa Siswa Perempuan. 


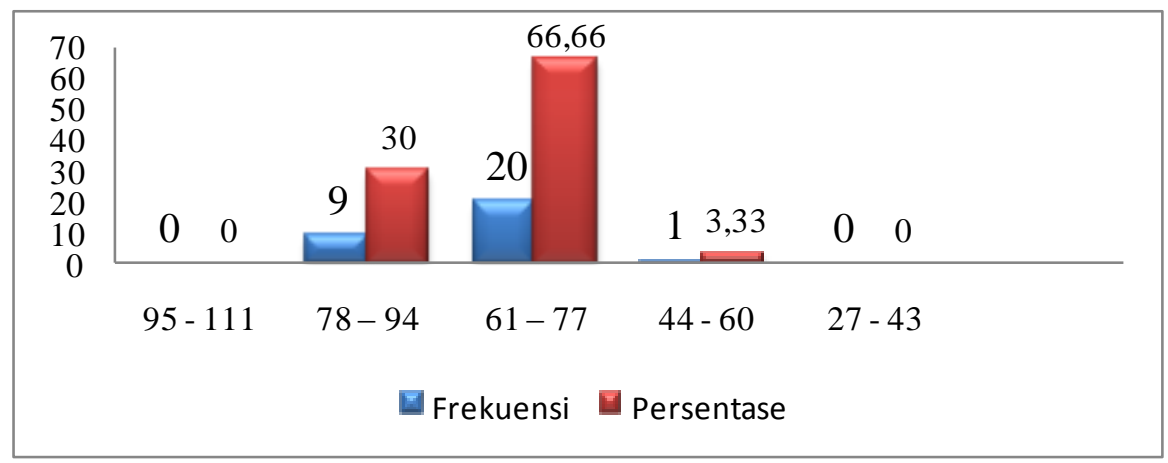

Gambarl 4.4 Gambar Histogram distribusi Frekuensi Data Self Awareness (Kesadaran Diri) Terhadap Nilai-Nilai Budaya Lokal Jawa Siswa Laki-Laki.

Tabel 4.5 Analisis Uji-t

Independent Samples Test

\begin{tabular}{|c|c|c|c|c|c|c|c|c|c|c|}
\hline & & \multicolumn{2}{|c|}{$\begin{array}{l}\text { Levene's } \\
\text { Test for } \\
\text { Equlity of } \\
\text { variances }\end{array}$} & \multicolumn{7}{|c|}{ t-tes for Equality of means } \\
\hline & & $\mathrm{F}$ & Sig. & $\mathrm{t}$ & df & $\begin{array}{c}\text { Sig. } \\
(2- \\
\text { tailed) }\end{array}$ & $\begin{array}{c}\text { Mean } \\
\text { Difference }\end{array}$ & $\begin{array}{l}\text { Std. Error } \\
\text { Diffenence }\end{array}$ & \multicolumn{2}{|c|}{$\begin{array}{c}95 \% \text { Confidance } \\
\text { interval of the } \\
\text { difference }\end{array}$} \\
\hline & $\begin{array}{l}\text { Equal } \\
\text { variances } \\
\text { not } \\
\text { assumed }\end{array}$ & & & 4.928 & 234.8 & .000 & -8.993 & 1.825 & -12.59 & -5.398 \\
\hline
\end{tabular}

Berdasarkan hasil Uji-t yang telah dilakukan diperoleh hasil bahwa ada perbedaan yang signifikan antara perilaku prososial dan self awarenes siswa laki-laki dan siswa perempuan. Taraf signifikasi yang digunakan dalam penelitian ini adalah 0,05 , sehingga dinyatakan terdapat perbedaan apabila nilai signifakasi penelitian lebih kecil dari taraf signifikasi yang ditetapkan yaitu 0,05 . Dalam Uji-t diatas nilai signifikasi penelitian 0,000.

Berdasarkan hasil analisis data tersebut diketahui bahwa ada perbedaan antara perilaku prososial dan self awareness (kesadaran diri) terhadap nilai-nilai lokal budaya jawa di tinjau dari jenis kelamin 
siswa kelas X SMA Kyai Ageng Basyasriyah Tahun Ajaran 2015/2016. Pada hipotesis pertama menunjukan bahwa terdapat perbedaan perilaku prososial antara siswa perempuan dan laki-laki. Hasil menujukkan bahwa siswa perempuan cenderung memiliki perilaku prososial lebih tinggi di bandingkan laki-laki, seperti yang tampak pada data histogram yang peneliti sajikan.

Selain pada perilaku prososial peneliti juga melakukan penelitian yang sama yaitu mencari perbedaan antara siswa perempuan dan laki-laki pada aspek kesadaran diri terhadap nilai-nilai lokal budaya jawa, dimana karakter lokal budaya jawa mulai sedikit luntur di kalangan remaja. Hasil penelitian menujukkan ada perbedaan anatara siswa perempuan dan laki-laki. Yaitu siswa laki-laki cenderung lebih mampu menamkan nilai-nilai lokal budaya jawa dalam kehidupan sehari-harinya di bandingkan dengan siswa perempuan.

\section{DAFTAR PUSTAKA}

Ahmad H. 2013. Kesadaran Diri (Self Awareness). Topic seminar (Online), (hariadimemed.blogspot.co.id/ 2013, diunduh pada 14 Maret 2016).

Asih G.Y \& Pratiwi M.M.S. 2010. Perilaku Prososial Ditinjau dari Empati dan Kematangan Emosi. Jurnal (Online). Vol 1, No.
(jurnal.umk.ac.id/index.php/PS

I.Diunduh pada 16 Maret 2016).

Desmita Y. 2014. Psikologi Perkembangan Peserta Disik. Bandung: PT Remaja Posdakarya.

Dewi N.K. (2013). Pengembangan Model Layanan Bimbingan Kelompok Berbasis Nilai Karakter Lokal Jawa Untuk Meningkatkan Kesadaran Diri (Self Awareness) Siswa. Tesis Tidak Diterbitkan. Semarang. Program Pascasarjana Bimbingan dan Konseling Universitas Negeri Semarang.

Gunawan, Heriati. 2010. Nilai-nilai lokal sebagai daya hidup masyarakat. Bandung: HIMPSI

Mayers D.G. 2012. Psikologi Sosial. Jakarta: Penerbit Salemba Humanika.

Meihati N.I, Sukarti, \& Nuh'man M.T. 2003. Hubungan Antara Perilaku Prososial dengan Kebermaknaan Hidup Pada Remaja. Jurnal (Online). Vol.1, No.1. (www.eprints.ac.id. Diunduh pada 20 maret 2016).

Prasetyo M.N. 2014. Membangun Self Awareness. Artikel (Online).

(www.m.wikipedia.org. diunduh pada 21 maret 2016)

Rachim R.L. \& Nashori H.F. 2007. Nilai Budaya Jawa dan Perilaku Nakal Remaja Jawa. Jurnal (Online). Vol.9, No.1. 
(https://publikasiilmiah.ums.ac. id.diunduh pada 20 Maret 2016).

Romlah, Tatiek. 2006. Teori dan Praktek Bimbingan Kelompok. Malang : Universitas Negeri Malang

Sarwono W.S \& Meinarno A.E. 2009. Psikologi Sosial. Jakarta: Salemba Humanika

Sarwono W.S. 2015. Psikologi Lintas Budaya. Jakarta: PT Rajagrafindo Persada.

Sugihastuti \& Septiawan H.I. 2007. Gender dan Inferioritas Perempuan, Praktik Kritik Sastra Feminis. Yogyakart: Pustaka Pelajar.
Sugiyono. 2013. Metode Penelitian Manajemen. Bandung: Alfabeta. 2013. Metode Penelitian Kombinasi (Mixed Methods). Bandung: Alfabeta 2015. Metode Penelitian Pendidikan. Bandung: Alfabeta

Taylor S.E, Peplau L.A \& Sears D.O. 2009. Psikologi Sosial, Edisi Kedua Belas. Jakarta: Kencana Prenada Media Group.

Widyastuti Y. 2014. Psikologi Sosial. Yogyakarta: Graha Ilmu.. 